[Agr. Biol. Chem., Vol. 31, No. 2, p. 259 260, 1967]

\title{
Novel Active Chrysanthemic Esters
}

Sirs:

Exploratory works have been made in search for novel pyrethroids-type insecticides, and we wish, at this time, to report some preliminary results of syntheses and bioassay of novel chrysanthemic esters, having 5-substituted furfuryl alcohols as alcoholic components other than cyclopentenolones.

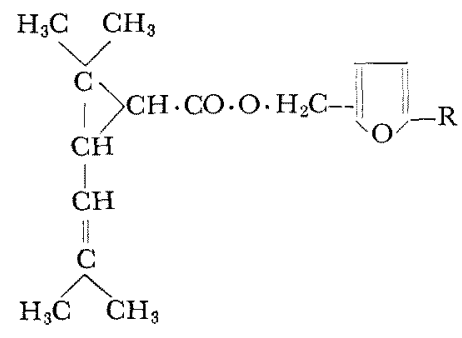

These esters were prepared by esterification of the respective 5-substituted furfuryl alcohols with isomeric chrysanthemoyl chlorides in the presence of organic bases. The IR-spectra of these compounds fully substantiated the ester-structure proposed.

Table I. Bolling Points and Refractive Index of the Compounds

Steric configurations of the acid moiety in the esters

$\begin{array}{cl}\text { I } & \text { dl-cis-trans } \\ \text { II } & \text { dl-cis-trans } \\ \text { III } & d \text {-cis-trans } \\ \text { IV-1 } & d \text {-cis-trans } \\ \text { IV-2 } & d \text {-trans(natural) }\end{array}$

$\begin{array}{lc}\mathrm{bp},{ }^{\circ} \mathrm{C} / \mathrm{mm} \mathrm{Hg} & n_{\mathrm{D}}^{25} \\ 105 \sim 107 / 0.20 & 1.4920 \\ 117 \sim 118 / 0.15 & 1.4948 \\ 130 \sim 131 / 0.60 & 1.5133 \\ 120 \sim 122 / 0.22 & 1.4980 \\ 119 \sim 121 / 0.20 & 1.5001\end{array}$

TABLE II. EFFECTIVENESS OF $\alpha$-dl-trans ALLETHRIN AND 5-SUBSTITUTED FURFURYL ESTERS OF CHRYSANTHEMIC ACID TO ADULTS OF THE COMmON HOUSE Fly, Musca domestica vicina Macq. Applied TOPICALly ACETONe SOLUTion

$\begin{array}{ccccc}\text { Material } & \text { Knock-down after } & \text { 30 mins. } & \text { Mortality after 24 hours } \\ \text { KD-50 } & \begin{array}{c}\text { Relative } \\ \text { effectiveness }\end{array} & \text { LD-50 } & \begin{array}{c}\text { Relative } \\ \text { effectiveness }\end{array} \\ \text { I } & 0.342 \gamma / \text { fly } & 1.0 & 1.197 / \text { fly } & 1.0 \\ \text { II } & 10.688 & <0.1 & 24.938 & <0.1 \\ \text { III } & 0.510 & 0.7 & 1.273 & 0.9 \\ \text { IV-1 } & 0.994 & 0.3 & 0.545 & 2.2 \\ \text { IV-2 } & 0.074 & 4.6 & 0.153 & 7.8 \\ & 0.028 & 12.2 & 0.101 & 11.9\end{array}$


It is noteworthy that the compound IV, 5-allylfurfuryl chrysanthemate, ${ }^{*}$ is 5 to 12 times as toxic as allethrin against common house fly and showed low toxicity to mammals, the acute oral LD-50 being above $10 \mathrm{~g} / \mathrm{kg}$ for compound II and $9.7 \mathrm{~g} / \mathrm{kg}$ for compound IV to mouse. Based on the previous knowledge of allthrin and benathrin, " together with the present study, $-\mathrm{CH}_{2}-\mathrm{CH}=\mathrm{CH}_{2}$ substituent

* For convenient sake, 5-allylfurfuryl chrysanthemate is proposed to be designated as "Japothrin", and 5-methylfurfuryl chrysanthemate as "Jamethrin" "

1) Y. Katsuda and H. Ogami, Botyu-Kagaku, 31, seems to play an important role in effecting insecticidal activity of chrysanthemates. Details will be published elsewhere.

\section{Yoshio Katsuda \\ Hiroshi OgamI \\ Tsutomu Kunishige** \\ Yasuji SugrI**}

Research Laboratory of Dainippon Jotyugiku Co., Ltd.

**Shiono Koryo Kaisha, Ltd..

Received December 24, 1966 